\title{
The Praxis of Digital Information Consumption to Change Student Behavior During Pandemic
}

\author{
Danil Putra Arisandy ${ }^{1 \bowtie}$, Muhammad Mukhlis ${ }^{2}$ \\ ${ }^{1}$ Department of Islamic Communication and Broadcasting, IAIN Langsa, Indonesia \\ ${ }^{2}$ Department of Islamic Communication and Broadcasting, IAIN Langsa, Indonesia \\ 凶email: danilarisandy@iainlangsa.ac.id
}

\begin{tabular}{ccc}
\hline First received: & Revised: & Final Accepted: \\
19 October 2021 & 13 November 2021 & 27 December 2021 \\
\hline
\end{tabular}

\begin{abstract}
This study aims to find out the consumptive practices of students as social media users and behavior changes felt due to frequent consumption of content from social media during the Covid-19 pandemic. In 2020, internet-based social media was also a new behavior and lifestyle in learning and teaching activities. The study used naturalistic inquiry methods, which resulted in writing or words and student behavior. Because to illustrate complex and concrete social realities, this study has interviewed IAIN Langsa students during the covid-19 pandemic. This research is descriptive of analytics by providing an overview of the objects studied. Sampling by snowball method makes it very easy for researchers to know students who are very active using social media. This study further used theory receptions where researchers analyzed students as social media users in the covid-19 pandemic in 2021, which is closely related to behavioral changes, namely from inclusive to exclusive or vice versa from exclusive to inclusive. This study shows that consumptive digital information practices through social media affect students, especially to changes in religious behavior, from inclusive behavior to exclusive behavior. However, this behavior is only limited to behavior in religious worship, not socio-cultural behavior. The findings of this study are that students who actively use social media can already distinguish between positive and negative content produced by online media consumed daily. After consuming social media content, students can choose and conduct studies before applying in everyday life.
\end{abstract}

Keywords: Social Media; Exclusive; Inclusive; Behavior; Naturalistic Inquiry Methods.

\section{INTRODUCTION}

The rise of digital media as a means of communicating during the covid-19 pandemic makes researchers feel that digital media has an essential role in providing positive and negative information to its users. Positive information is undoubtedly considered favorable and wellreceived information among digital media users (W, 2009). Meanwhile, the negative information will negatively impact targeting the mindset and deviant behavior to reflect it in daily activities (Abdul Rahin Bin Hamdan et al., 2018).

They started discussing with colleagues whether students' activities to do learning during the covid-19 pandemic using the internet network will accommodate their activities for learning? During the pandemic teaching and learning process at universities is required to use applications on the internet network (zoom meeting) in discussions that researchers conduct with friends that lead to a question that is unable to be answered by the discussion participants. During the discussion, participants suggested looking for answers to that 
question in the Google search engine. While smiling, it searched on the search engine (Google Search Engine). Finally, the answer to that question came from that source. It turns out that Google has so much digital information that its users can consume to get all sorts of questions. However, Google does not necessarily give the correct answer because its users must also understand and check back by looking at other links that provide the same information as the initial question they want to ask (Kurniadi \& Mulyani, 2017).

Google's search engine can search for its users' questions based on the letters and numbers available on the Web. Especially students looking for journals and books uploaded by publishers or applications that provide journals and books will be very easy to get in a positive way, which later students will use these sources as material in lectures conducted online at the student's college (Haq, 2017). This study highlights how the consumption of digital information sourced from the Web, whether it impacts students' thinking patterns, is further expressed in everyday behavior, both exclusive behavior and inclusive behavior, especially in religious society.

Students will get religious information through the Web, consume it, and then impact changes in behavior from not knowing to knowing something new and causing changes in negative attitudes and positive attitudes. This behavior can be seen through a closed attitude (exclusive) or an open (inclusive) attitude, where this attitude comes from how students understand the information obtained through digital media (internet) (Pramiyati et al., 2016).

Research on inclusive and exclusive behavior has been widely conducted where the results of research on activist students of the Universitas Indonesia (UPI), especially the department of Islamic Religious Education. It is more likely to have an exclusive pattern of thinking about religion, its implications, religious development in lectures and seminars conducted need to balance the tendency of the dai who are role models of society and the source of reading books and media. Digital is inclusive. Unlike the case with Islamic activist students who are active in HMI / PMII / IMM, they tend to be liberal and inclusive thinking patterns (Mulawarman \& Nurfitri, 2017).

This study is different from existing research, and this study focuses on IAIN Langsa students who consume information through digital media that produce behavioral changes during the covid-19 pandemic in Langsa City. This behavior is focused on exclusive and inclusive behavior to answer the concepts of tolerance of thought and religious moderation to create comfort and peace. 
Where previous studies on behaviors arising from the effects of consuming social media. Scholars have also discussed it to get information or entertainment. Yose Rizal Damuri said consuming digital media is inevitable in Indonesia, where technological innovation towards digitization of the industrial revolution 4.0 is a new model to improve daily activities, including learning and teaching (Damuri et al., 2020).

The use of social media that has a positive and negative impact is highlighted by scholars in various countries, such as Robin Thompson in East Africa and North Africa. Internet social media is used to send messages of radicalism, both in text messages and videos that can be very easily accessed with the internet network (Thompson, 2011).

Students experience behavior change due to consuming social media, leading to actions or actions. The action can take the form of violations of the law or actions that are not commendable. Jarred Prier says social media is often used as a weapon for war. Pier said social media is used as a tool for propaganda with an extensive reach because media messages can be arranged to look like a trending topic that is undoubtedly a student consumption (Prier, 2017).

Kirdemir's line in his report is titled “Turkey's Digital News Landscape: Polarization, Social Media, And Emerging Trends." Saying that social media is particularly vulnerable to attempts at political polarization, disinformation, individual or group interests, all of which have formed an ecosystem in Turkish media, Baris points out that social media is particularly vulnerable to the efforts of certain people with specific goals both good and bad (Kirdemir, 2020).

\section{METHOD OF RESEARCH}

This research is a naturalistic inquiry approach because the data to be studied describes complex and concrete social realities. This research is descriptive of analytics. Bogdan and Taylor in Moleong define qualitative methodology as a research procedure that produces descriptive data in written or spoken words from people and observable behaviors (Moleong, 2005, p. 4). Qualitative research is data collected in words, images, and not numbers. Nevertheless, data in the form of numbers may be needed to support qualitative data obtained. The data obtained includes interview transcripts, field records, photographs, personal documents, and so forth (Faisal, 1999).

Based on the understanding of qualitative research put forward by experts, the behavior of everyone who plays a role directly or indirectly has relevance to this research can be a source of data. 
In this study, using snowball sampling is one method in sampling a population. Snowball sampling is included in the nonprobability sampling technique (samples with unequal probabilities) (Nurdiani, 2014).

This research collects information and inputs obtained through interviews and from the observations of individual behavior studied related to the religious behavior of IAIN Langsa students.

The implementation of research is carried out systematically by 1) determining social situations, 2) making observations in the field, 3) determining data collection techniques, 4) determining data analysis techniques, 5) discerning the validity of data, 6) formulating findings, and 7) compiling research report.

The study used a theory of reception. Researchers analyzed students as social media users in times of the covid-19 pandemic closely related to behavioral changes, namely from inclusive behavior to exclusive behavior or vice versa from exclusive behavior to inclusive behavior (Hadi, 2010).

\section{RESULT AND DISCUSSION}

The results showed that students prefer the Google search engine to get the information they want to search for on the internet. They feel this search engine is prevalent among internet users and very easy to use; quickly getting what they are looking for on the internet will make it popular among students (Kurniadi \& Mulyani, 2017). Besides being easy, this machine also directly provides what is sought after, such as journal websites and books. According to alphabetically, although sometimes have to sort and choose because what is sought sometimes has similarities to be displayed sequentially (IAIN Langsa student, interview, October 11, 2021).

In using digital media in addition to lecture assignments, students also often watch videos from www.youtube.com, Tiktok application, Like and the like which prefer lectures from dai from various countries, both local and international such as (Ustadz Zakir Naik), (Ustadz Abdul Somad), (Ustadz Adi Hidayat) where students tend to learn religious science from ustad and dai lectures.

Consuming religious information through digital media can significantly change the mindset and attitudes of students. It has an impact on increasing religious understanding, namely the history of religion, Islamic law, Islamic communication, and exclusive attitudes and behaviors begin to decrease, if viewed selectively, then the changes experienced are Islamic 
dress procedures and improve morals and words that are more polite to others in everyday life (IAIN Langsa student, interview, October 12, 2021).

If students access to content about religion, the results add to faith and obedience, behavior is more muhasabah, meaning that the form of behavior change has varied, it could be a change in faith and obedience from the beginning which is less to increase also obedience to the creator. Nevertheless, there are positive and negative impacts in consuming information from Google. If the content accessed is a positive thing, it will be positive knowledge gained, and if negative, it will undoubtedly produce negative behavior.(Zamakhsari, 2020) However, every student who gets information will undoubtedly study the truth first to avoid getting misleading information (fake news) so that it even damages faith and piety to Allah SWT (IAIN langsa student, interview October 13, 2021).

Exclusive behavior for students is lousy and seems to brag, exclusive behavior that means alone, not together, separated, making an impression and image that is not good for other friends because exclusive is the behavior that he believes that his thoughts and views are correct, while the thoughts and ideas of others are considered untrue.

This exclusive behavior is undoubtedly hazardous if linked to religion because it impacts closed behaviors and stays away from people considered different from themselves to cause gaps in fellow human beings. The consumption of information through digital media certainly does not all have positive content, and it can contain an exclusive pattern of thought that considers other religions different from him. This understanding is meant to be exclusive thinking, not accepting other religions in terms of emotional relationships, friendships, fellow citizens, and statehood.

At first, this complete understanding is a traditional behavior deeply rooted in lowermiddle society, whose religion is the only truth, so it must be closed to people who adhere to other religions.

This exclusive is divided into two types, namely external and internal exclusive. This external exclusive unconsciously often occurs among students; exclusive behavior is not without reason. The reason this exclusive behavior out, or to non-Muslims based on the verse (Quran: Ali-Imran, 19) that is:

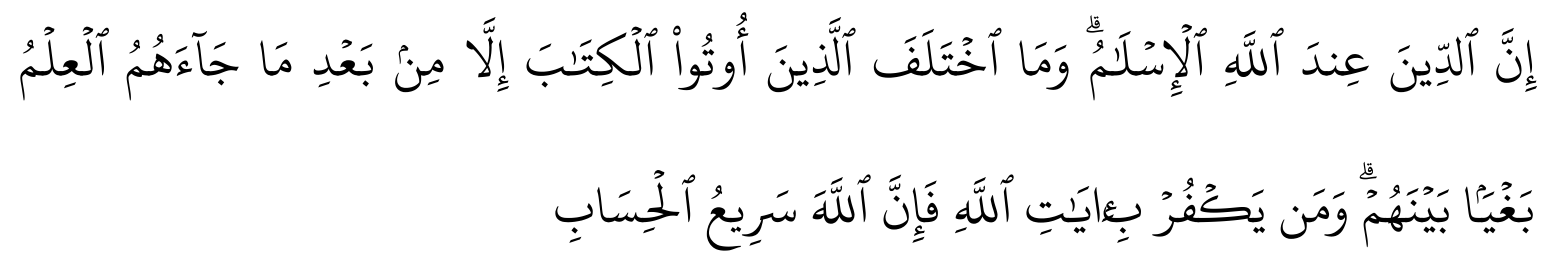


'Indeed, the religion in the sight of Allah is Islam. And those who were given the Scripture did not differ except after knowledge had come to them - out of jealous animosity between themselves. And whoever disbelieves in the verses of Allah, then indeed, Allah is swift in'

The verse has made it clear that the religion of Islam is the religion of Allah SWT. There is no dispute for those given the Book unless there is already knowledge. The opinion of exclusivism says that Islam is the religion brought by the Prophet Muhammad, and Allah Swt guides this religion alone. (book "K.H Zainal Arifin Abbas" 1984 h. 32) while religions other than Islam are not guided.

Exclusive is the behavior of a person who claims that only the school or school he embraces is proper, while the other school is considered untrue. Exclusive behavior into this also occurs among internal Muslims, and this is due to differences in reading that make the birth of closed behavior of fellow Muslims, although if traced further that this behavior arises because of a bit of understanding of religious science so that different points of view will make a difference in the way of thinking. Although different thoughts of exclusive behavior do not significantly create a gap among Muslim students, it will only give birth to debate among Muslims to increase knowledge about religion in-depth to be implemented.

In this case, IAIN Langsa students strongly avoid exclusive behavior that is open (Habibi, 2017). This means that it is not debated in public areas such as social media, students usually conduct this debate in internal official forums or in lectures, where this is done so that the difference can be answered carefully by lecturers or to people who are considered more experts in the field of religious understanding (interview results).

This inclusive behavior is the student who holds that religious truth is relative. The absolute truth is the teachings of the Qur'an and the hadith of the Prophet Muhammad (peace be upon him). The understanding of Islam is not perfect, and Islam has many schools that can sometimes have differences from each other. While inclusive behavior comes out is a student who argues that religion other than Muslims, it is true in the view of the followers. Thus, we do not need to take care of non-Muslim religious affairs. Religious affairs are a matter of privacy for those of different religions. In terms of social interaction relationships, we can still be neighborly, friends, states, help each other and share in all things. This behavior can be said to be religious moderation behavior, where students can choose where the similarities and differences are in privacy, and some are social.

This inclusive behavior has become a habit for IAIN Langsa students because they are neighbors with non-Muslim students from North Sumatra who are continuing their studies at public universities (UNSAM Langsa) located in Langsa and adjacent to the IAIN Langsa. In 
everyday association, students give certain restrictions with non-Muslim students, and this limit is only in acts of worship, such as performing worship which is for non-Muslim students to worship in church, while Muslims worship at home or in mosques (Casram, 2016).

Aceh province as an area that implements Islamic sharia, the most striking difference is the way to dress for women, especially for Muslim women in everyday life outside the house using Muslim clothing that we commonly call hijab or veil, but for non-Muslim women only required to dress politely, not required to wear Muslim clothing such as the hijab. Therefore, if students gather in daily activities, non-Muslim women will look different from Muslim women. However, the apparitions did not have a significant influence on Muslim students. Muslim women still understand differences and tolerate non-Muslim women. This proves that consuming information through digital media does not make students behave exclusively to minorities, even though different religions, fashions, or thoughts.

Some IAIN Langsa students who are neighbors of non-Muslim students admit that in their daily lives, they also often do off-campus activities together with non-Muslim students, such as coffee drinking, recreation, and shopping activities. In carrying out these activities, they never distinguish between Muslims and non-Muslims, keep normal activities as other activities without any conflict that leads to racism and the like.

Non-Muslim students also positively responded to Muslim students and socially connected well, which could not be influenced by the news on social media about Muslim and non-Muslim conflicts. Non-Muslim students consider that content on social media can not be used as a good source of information because there needs to be an in-depth check. NonMuslim students also judged that whatever content occurred on social media did not make him misbehave to fellow students because personal life and virtual life could not be put together.

Students consider that content on social media should be considered a means of entertainment, except content based on Islamic proselytizing delivered by speakers who are well known both in cyberspace and in the real world and can be accounted for the content of da'wah. Although the da'wah content is available on Youtube, Tiktok, Web is filled with many famous dai-dais, students are more interested in listening to da'wah than those who are familiarly known, students do this to avoid radicalism, intolerance, misinformation, or teachings that are not by the schools embraced in Indonesia. Students prefer dai, who has a relatively young age and often discuss young millennials in the face of the digitalization era. 
Muslim students who behave exclusively in a religious society are not because of dislike of non-Muslim students, but this is done to avoid unwanted things. Muslim students consider religious issues a sensitive area for believers and are very private. This area of privacy is why every one of different religions must carefully maintain each other's boundaries to maintain good relations with religious people.

This exclusive behavior also arises because of the consumption of information on youtube social media that discusses how Muslims behave towards non-Muslims in the religious field. Students concluded that Muslims and non-Muslims have social bonds among human beings as countrymen. Nevertheless, religious ties are certainly different areas because of religious activities and different ritual ordinances, different teachings, so in this case, Muslim students restrict non-Muslim friends to participate in the religious activities of Muslims.

Although limiting non-Muslims to participate in religious activities, Muslim students remain inclusive if non-Muslims desire to learn or ask about the teachings of the Muslim religion, and vice versa for Muslim students.

\section{CLOSING}

This study shows that consumptive praxis on social media affects changes in student behavior. Youtube, TikTok, and the like have significant positive and negative effects. However, the apparent effect is to change the understanding of the religious mindset of students, which will be a change in the exclusive behavior of religious society. However, this change has not hurt daily actions, such as hostile actions or distancing themselves from social activities towards other students with different mindsets or religions. As for the exclusive behavior that appears in action, namely to students of different religions, namely closed behavior or attitudes in carrying out daily religious worship. This behavior was born because of the assumption that students who have different religions certainly feel they will not be in line with him. The student judged that there is no need to have inclusive behavior or be open to other religions in terms of religious worship. The difference in mindset in religious science, among others, is still considered reasonable because the students consider it is a guide given by the creator to each different individual in understanding the teachings of religion.

\section{BIBLIOGRAPHY}

Abdul Rahin Bin Hamdan, Ahmad Johari Bin Hj Sihes, Jamaluddin Bin Ramli, Rosliza Binti Hamzah, Bernama, Ezaleila Mustafa, S., Hamid, S. A., Ibrahim, J., Nasrullah, R., Amir, O. A., Saidi, F. S., Adrianto, m, W., Mohd Hilmi Mohd Hashim, Muhd Zulkifli Ismail, 
Nik Farhan Mustafa, Mohamad, H., Paruzzaman, N. A., Does, H. O. W., Apply, I. T., ... Sonenthal, A. (2018). Media Sosial. Www.Moe.Gov.My, 1(1), 1-8. https://www.cliffsnotes.com/study-guides/sociology/social-change-andmovements/models-of-socialchange\%250Ahttps://www.moe.gov.my/index.php/my/dasar/falsafah-pendidikankebangsaan\%250Ahttp://www.utusan.com.my/rencana/positif-negatifnya-media-sosial1.1693

Casram, C. (2016). Membangun Sikap Toleransi Beragama dalam Masyarakat Plural. Wawasan: Jurnal Ilmiah Agama Dan Sosial Budaya, 1(2), 187-198. https://doi.org/10.15575/jw.v1i2.588

Damuri, Y. R., Fauri, A., \& Rafitrandi, D. (2020). Perkembangan dan Regulasi E-commerce di Indonesia. Centre for Strategic and International Studies. http://www.jstor.org/stable/resrep28867

Faisal, S. (1999). Format-Format Penelitian Sosial. Remaja Rosdakarya.

Habibi, M. M. (2017). Corak pendidikan islam inklusif. EL-Tarbawi ; Jurnal Pendidikan Islam, $\mathrm{X}(1), 35-48$.

Hadi, I. P. (2010). PENELITIAN KHALAYAK DALAM PERSPEKTIF RECEPTION ANALYSIS. Scriptura, 3(1). https://doi.org/10.9744/scriptura.3.1.1-7

Haq, M. Z. ul. (2017). Googledork, sebuah pendekatan lanjutan pemanfaatan mesin pencari sebagai penunjang literasi informasi. UNILIB: Jurnal Perpustakaan, 8(1), 2. https://doi.org/10.20885/unilib.vol8.iss1.art3

Kirdemir, B. (2020). TURKEY'S DIGITAL NEWS LANDSCAPE. Centre for Economics and Foreign Policy Studies. http://www.jstor.org/stable/resrep26092

Kurniadi, D., \& Mulyani, A. (2017). Pengaruh Teknologi Mesin Pencari Google Terhadap Perkembangan Budaya dan Etika Mahasiswa. Jurnal Algoritma, 14(1), 19-25. https://doi.org/10.33364/algoritma/v.14-1.19

Machendrawaty, N., \& Safei, A. A. (2001). Pengembangan Masyarakat Islam: Dari Ideologi, Strategi, sampai Tradisi. Bandung: Remaja Rosdakarya.

Moleong, L. J. (2005). Metodelogi Penelitian Kualitatif. Remaja Rosdakarya.

Mulawarman, M., \& Nurfitri, A. D. (2017). Perilaku Pengguna Media Sosial beserta Implikasinya Ditinjau dari Perspektif Psikologi Sosial Terapan. Buletin Psikologi, 25(1), 36 - 44. https://doi.org/10.22146/buletinpsikologi.22759

Nurdiani, N. (2014). Teknik Sampling Snowball dalam Penelitian Lapangan. ComTech: Computer, Mathematics and Engineering Applications, 5(2), 1110. https://doi.org/10.21512/comtech.v5i2.2427

Pramiyati, T., Purwarianti, A., \& Supriana, I. (2016). KECENDERUNGAN PENILAIAN PENGGUNA INFORMASI TERHADAP TWEET (KICAUAN) PADA MEDIA SOSIAL TWITTER. Simetris : Jurnal Teknik Mesin, Elektro Dan Ilmu Komputer, 7(1), 
209. https://doi.org/10.24176/simet.v7i1.506

Prier, J. (2017). Commanding the Trend. Strategic Studies Quarterly, 11(4), 50-85. http://www.jstor.org/stable/26271634

Thompson, R. (2011). Radicalization and the Use of Social Media. Journal of Strategic Security, 4(4), 167-190. http://www.jstor.org/stable/26463917

W, A. C. (2009). Etika berkomunikasi dalam penyampaian aspirasi. Komunikasi.

Zamakhsari, A. (2020). Teologi Agama-agama Tipologi Tripolar; Eksklusivisme, Inklusivisme $\begin{array}{llll}\text { dan Kajian } \quad \text { Pluralisme. } & \text { Tsaqofah, }\end{array}$ https://doi.org/10.32678/tsaqofah.v18i1.3180. 